\title{
Liability for Damage to Health Due to Limited Access to Health Care during Emergency of the Covid-19 Pandemic
}

\author{
Stanislav Bílek ${ }^{1, *}$ \\ ${ }^{1}$ Institute of Technology and Business, Faculty of Corporate Strategy, Okruzni 517/10, 37001 České Budějovice, Czech Republic
}

\begin{abstract}
Most successful companies have established effective marketing communication as a useful tool for selling their products to customers. The research explored the ways of communication of a selected internet subject, its methods of addressing customers and how effective the communication of the specific enterprise is not only during covid19 pandemic. We carried out a SWOT analysis, conducted a questionnaire survey and made detailed This paper discusses the responsibility / liability of the state and health service providers in relation to limited access by individuals to preventive as well as other outpatient or inpatient care as a result of the measures of the Government of the Czech Republic and the Ministry of Health of the Czech Republic during a declared state of emergency due to the coronavirus pandemic /referred to as SARS $\mathrm{CoV}-2 /$. The paper provides a legal analysis of the current legislation in health care services and the circumstances under which health care may be refused by its provider and discusses the possibilities of claiming compensation for damages incurred by affected persons as a result of limited access to health care. The survey is mainly focused on civil liability for non-pecuniary damage to health and human life and liability under the Crisis Management Act of the Czech Republic.
\end{abstract}

Keywords: emergency; general measures; liability for damage to health

\section{Introduction}

Limited access by individuals to preventive and outpatient health care during a state of emergency declared by the Government of the Czech Republic [1], which was subsequently extended by the Chamber of Deputies of the Parliament of the Czech Republic, entails one of the most serious impacts of the SARS CoV-2 pandemic, especially the effects on health of the affected persons. This happened repeatedly based on general measures adopted by the Ministry of Health of the Czech Republic [2], and health care providers were reducing preventive and outpatient care to follow these measures [3]. Compensation for damage to health, deterioration of health or death of a person causally related to limited access to health care may become the subject of many legal actions and disputes in the years to come where the liability of the state and health care providers for such damages will be addressed, taking into account the unprecedented state of emergency which has never before affected the function of public health to such extent.

A number of international studies across many disciplines were produced in the immediate aftermath of the SARS CoV-2 coronavirus pandemic outbreak, including papers examining the medical, sociological, legal and economic aspects of the pandemic. For example, the research of Firan and Fatine [4] who look at the economic consequences of the epidemic and point out that the choice of restrictive policies made it possible to reduce the negative medical impact of the pandemic. Another paper [5] emphasizes that the COVID-19 pandemic forced societies around the world to resort to social distancing in order to slow the spread of SARS-CoV-2.

But let us focus on the legal aspects of the pandemic that has occurred. The legal implications are also addressed by many international and national scientific studies and papers. Comazzeto [6] in his scholarly article discusses some aspects of the pandemic emergency, and analyzes the legal basis of the so-called lockdown with a focus on the definition of the "state of exception" in order to evaluate its function as the key concept in public law discourse. Barquero [7] reviews the legal requirements for court approval / ratification of health measures taken by public authorities, affecting the exercise of fundamental rights, including the interpretation doubts that have led to a high dispersion of criteria in judicial decisions.

The interplay between law and medicine can be seen in another author who addresses the system's response to the feared mass influx of patients in intensive care units as a result of the COVID-19 pandemic. Kern and Peters [8] analyze this and conclude, among other things, that it would be useful to be aware of and apply to the situation the basic knowledge of so-called disaster medicine even if this is not a disaster in the technical sense.

\footnotetext{
* Corresponding author: stanislav.bilek@mail.vstecb.cz
} 
The issue of political, institutional and professional responsibility in the context of the SARS-COV-2 pandemic is currently widely discussed and involves several levels of investigation. One crucial aspect is the allocation of life-saving resources in a situation where there is lack of balance between the need and availability and the related issues of ethical and legal responsibility. In this context, Gambino et al. [9], for example, discuss the implications of the criteria used for the allocation of benefits in emergency and the issue of their legitimacy.

Apparently, the legal and ethical implications of the pandemic impact on medicine and health care have a broader scope across all countries of the world. It is obvious the situation that has arisen is quite unique, with unexpected economic, health and social impacts influenced by, among other things, targeted legislative interventions by the state in the effort to prevent system overload. In this context, the author of this paper is looking at the impact of limited access to health care for citizens as a result of the state measures, focusing on national law and health care providers in the Czech Republic. The analysis of the current legislation overlaps foreign legislation in parallel as the citizen's right to protection of life and health and to the provision of health care is guaranteed by international conventions for the protection of human rights. During emergency, the state measures primarily limited access to preventive health care, but also to other health care for citizens of the Czech Republic and foreigners.

The aim of this paper is analyze the legal aspects of responsibility / liability of the state (the Czech Republic) and health care providers in the Czech Republic due to limited access by citizens to health care during a declared state of emergency.

The author asked the following research questions to fulfil the aim of the paper: 1 . Is the state responsible under the current legislation for damage to health caused by the postponement of health care due to the state emergency measures imposed during the state of emergency? 2. Is the health care provider responsible under the current legislation for damage to health caused by the postponement of health care due to the state emergency measures imposed during the state of emergency?

\section{Methodology}

The author uses a method of data collection consisting in content analysis of the current legislation, in particular constitutional laws, laws, government resolutions, and general measures as well as content analysis of case law and previously published scholarly articles related to the topic. The author's proposed measures are then built upon his private law practice.

The author analyzes (using legal interpretation methods) the content of the below documents to the extent necessary to fulfil the above aim. It is to be expected that national law has legal instruments to protect the affected persons in the normal course and function of the health care system. However, the crisis management legislation and the specific measures adopted by the state during emergency need to be particularly analyzed to determine the relationship (ratio) in emergency between the private citizen's health and life interest on the one hand and the public state interest in implementing measures to mitigate the global impact of the pandemic.

In terms of limited access to health care in the Czech Republic during the state of emergency, the following findings should primarily be taken into account.

The Charter of Fundamental Rights and Freedoms which forms the constitutional order of the Czech Republic reads (Article 31) that "Everyone has the right to health protection. Citizens have the right, on the basis of public insurance, to free health care and to medical aids under the conditions laid down by law." According to the Charter of Fundamental Rights and Freedoms, Article 6, "everyone has the right to life. Human life is worthy of protection even before birth. No one shall be deprived of life." [10].

The Constitutional Act No. 110/1998 Coll., on the Security of the Czech Republic, lays down the rules for limitations of the fundamental human rights. The institution of emergency is explained in Article 5 which states that "the Government may declare a state of emergency in the event of natural disasters, environmental or industrial accidents, incidents or other dangers that threaten life, health or property values or the internal order and security to a significant extent. The Government shall immediately inform the Chamber of Deputies of the declaration of a state of emergency which may revoke the declaration." Article 6 of the same constitutional law provides further details of rules for declaring a state of emergency: "A state of emergency may be declared only with reasons for a specific territory and for a specific period of time. In parallel to the declaration of a state of emergency, the Government must define which rights provided for in a special law are restricted and to what extent, in accordance with the Charter of Fundamental Rights and Freedoms, and which duties are imposed and to what extent. The details shall be laid down by law. A state of emergency may be declared for a maximum period of 30 days. That period may only be extended subject to the prior consent of the Chamber of Deputies. The state of emergency shall end upon the expiry of the period for which it was declared unless the Government or the Chamber of Deputies should decide to lift it before the expiry of that period." [11].

For the declaration of a state of emergency to be correct, among other things, the reasons therefore must be defined and it must be temporary and the territorial scope must be determined. Above all, however, the constitutional law imposes on the Government of the Czech Republic which rights stipulated in laws and the Charter of Fundamental Rights and 
Freedoms will be restricted by such a measure. As is evident from the text of the government resolution on the declaration of a state of emergency, there is no list of restricted rights although the constitutional law requires this to be defined "in parallel" with the declaration of the state of emergency [11].

The details of a state of emergency are regulated by Act No.240/2000 Coll., on Crisis Management and on Amendments to Certain Acts (the Crisis Management Act). We will particularly look at the possibility of compensation for damages arising out of or in connection with the implemented crisis measures. This Act defines the competence and authority of public authorities and regional government authorities and the rights and duties of legal and natural persons in preparing for and managing emergency and crisis that are not related to the defence assurance of the Czech Republic against external attacks and in protecting the critical infrastructure, and liability for breach of those duties and obligations. Before we analyze the issue of the state's liability for damage, the terms of crisis management and crisis measures should be defined. The crisis management is defined by the Act Section 2 as "The summary of management activities of crisis management authorities focused on analysis and evaluation of security risks and planning, organization, implementation and control of activities performed in connection with 1) preparation for crisis situations and their resolution, or 2) protection of critical infrastructure. A crisis measure denotes an organizational or technical measure intended to manage and mitigate a crisis situation and eliminate its consequences, including measures interfering with personal rights and duties." [12]. For the purposes of this paper, it is therefore important to conclude that crisis measures are the package of all measures adopted by various competent public authorities in the context of an emergency. The form of crisis measures may be a government resolution, a law, a decree, a general measure, an administrative decision, or any actual measures adopted by public authorities [13]. The Crisis Act Section 5 provides an exhaustive list of specific measures that may be imposed by the Government. None is about limiting access to health care [12].

On 12 March 2020, the Government of the Czech Republic adopted a resolution declaring a state of emergency for the territory of the Czech Republic due to a threat to global health in connection with the demonstrated presence of coronavirus /referred to as SARS CoV-2/ in the territory of the Czech Republic for a period of 30 days starting $2.00 \mathrm{pm}$ on 12 March 2020. The resolution was published in the Collection of Laws under No. 69/2020. It reads, inter alia, that: "In accordance with Article 5(a) to (e) and Article 6 of Act No. 240/2000 Coll., on crisis management and on amendments to certain acts (the Crisis Management Act), as amended, the Government hereby orders and adopts crisis measures to manage the crisis with the specific implementation of the measures to be determined under a separate resolution of the Government. "

On 9 April 2020, the Government extended the state of emergency until 30 April 2020 by resolution published in the Collection of Laws under No. 156/2020, with the prior consent of the Chamber of Deputies.

The Government of the Czech Republic repeatedly declared a state of emergency by its Resolution No. 957 of 30 September 2020, starting 5 October 2020, which was subsequently extended until 14 February 2021 with the approval of the Chamber of Deputies. Thereafter, the Chamber of Deputies did not approve the state of emergency, therefore the Government of the Czech Republic declared a new state of emergency by its Resolution No. 125 of 14 February 2021 for a period of 14 days from 15 February. The Constitutional Court of the Czech Republic, by its resolution no. ÚS 12/21 of 15 March 2021, rejected the petition for review of constitutionality of this action because of this declaration being a political act which is not subject to legal review. The Constitutional Court also described the declaration of a state of emergency as an unreviewable act of government in its previous decisions Pl. ÚS 5/21, Pl. ÚS 9/21 and Pl. ÚS 10/21. In the resolution Pl. ÚS 8/20 of 22 April 2020, the Constitutional Court explained that "the declaration of a state of emergency by the Government is, in the present case, primarily an act of application of constitutional law; it constitutes an 'act of government' which has a normative impact, in principle not subject to review by the Constitutional Court and may only be 'reviewed' by the primary democratically elected political ('non-judicial') body, which is the Chamber of Deputies. The emergency declaration act could be annulled by the Constitutional Court if it should contravene the fundamental principles of the democratic rule of law and if it should constitute a change in the essential elements of the democratic rule of law. In the resolution by which the state of emergency was declared, the Government defined the rights to be restricted by reference to Sections 5(a) to (e) and 6 of the Crisis Management Act and to other more specific Government resolutions. Although such an implicit definition is general and vague, it cannot be regarded as an expansive violation or abuse of constitutional law. The above formal deficiency cannot be inferred to invalidate the decision to declare a state of emergency since an overly strict assessment of formal requirements would completely disregard the seriousness and exceptional nature of the situation which led to the declaration of a state of emergency." [14].

On the other hand, the Municipal Court in Prague concluded that the declaration of a new state of emergency was unconstitutional and illegal, in its judgment No. 17 A 126/2020- 84 dealing with the distance learning case, providing the reasons that "This is not a new state of emergency, but a de facto continuation of the state of emergency declared by Government Resolution No. 125, against the will of the Chamber of Deputies, which did not consent to the continuation of this state of emergency." [15].

On 27 February 2021, Act No. 94/2021 Coll., on Emergency Measures during the COVID-19 Disease Epidemic, became effective and replaced this institution with the so-called pandemic emergency.

The following general measures adopted by the Ministry of Health of the Czech Republic are the first to be taken into account with regard to limited access to health care during the state of emergency. During the state of emergency from 
12 March to 17 May 2020, the first general measure was adopted on 16 March 2020, Ref. MZDR 12066/20201/MIN/KAN, by which the Ministry of Health ordered the health care providers of acute inpatient care services to reduce the medical procedures within elective care to the extent strictly necessary, taking into account the state of health of the patients for whom such medical procedures were scheduled to ensure a sufficient capacity and resources (personnel, material and technical) for the treatment of patients with covid-19 disease, with effect from 17 March 2005 (repealed with effect from 18 May 2020 by the measure Ref. MZDR 12066/2020-2/MIN/KAN). This measure essentially restricted health care other than acute.

Similarly, during the so-called second wave of the pandemic, the Ministry of Health adopted the measure Ref. MZDR 46953/2020-1/MIN/KAN on 26 October 2020, by which acute inpatient care providers were ordered to immediately stop admitting new patients for the purpose of elective procedures. This order was repealed with effect from 24 November 2020 by the Ministry of Health's measure of 23 November 2020, Ref. MZDR 46953/2020-2/MIN/KAN. At the same time, however, this new measure ordered "All providers of acute inpatient health care services with effect from 24 November 2020, and all providers of inpatient follow-up and long-term care, including intensive follow-up, to take measures in order to ensure the necessary and adequate personnel, material and technical resources for providing health services to patients with COVID-19 disease caused by the new SARS-CoV-2 coronavirus such that acute inpatient care providers who have previously been involved in the provision of inpatient care to patients with COVID-19 disease should maintain the necessary capacity of available acute care beds, including intensive care beds, for patients with COVID19, according to the current epidemiological situation and predicted need for hospital care, and inpatient follow-up care providers should maintain the necessary capacity of available follow-up care beds to receive patients transferred from acute care". These measures were then extended until they were definitively repealed on 1 July 2021 by the emergency measure Ref. MHDR 46953/2020-8/MIN/KAN.

For the sake of completeness, note that the measures were adopted by the Ministry of Health as crisis measures under the Crisis Management Act, but with reference to Section 69(1)(d) and (i) and (2) of Act No. 258/2000 Coll., on the Protection of Public Health, as amended. And measures adopted under legislation other than the Crisis Management Act should also be regarded as crisis measures [14]. In accordance with the Act on Protection of Public Health, the Ministry of Health may order to, in particular, close day care or inpatient care facilities and allocate beds in health care facilities, and it may order or prohibit some other specific activities to eliminate an epidemic or the risk of an epidemic. Emergency measures are imposed to the extent strictly necessary in accordance with Section 69 of the Act [16].

A specific example of the implementation of such measures is the decision of the České Budějovice Hospital of 6 January 2021 to postpone all elective procedures / hospitalizations scheduled until 31 January 2021 where it is medically safe according to the emergency measure of the Ministry of Health of the Czech Republic "without significant impact on the health of patients". It was explicitly stated that "The scheduling of new patients for these procedures will be stopped. The decision to postpone specific types of procedures will always be up to the head of the department. Patients concerned will be informed by the medical staff by phone, text message or email as in the spring and autumn. Patients will be rebooked for a new appointment when full operations resume. We ask those who have had a procedure cancelled to contact us if their health should deteriorate. This measure does not apply to the treatment of acute illnesses and diseases where the postponement could lead to damage to patients' health (in particular, cancer surgery, cardiovascular and thoracic surgery, or major orthopaedic procedures for symptomatic patients). For patients who have already been admitted to the hospital for these procedures, the scheduled procedure will be performed. Similar to the autumn, this is approximately a 50\% reduction in care." The partial limitation specifically affected elective care in the Surgery, Urology, Gynecology, Skin and Venereal Diseases, Neurosurgery and Cardiology Departments. Health care was similarly reduced by other providers regardless of their legal form and it was regularly reported in the media [3].

For analysis of the topic, it is also necessary to briefly describe the individual types of health care according to Sections 5 to 9 of Act No. 372/2011 Coll., on Health Services and Conditions of Their Provision (the Health Services Act), as amended. The types of health care are divided according to the urgency of their provision into urgent care, emergency care, essential care and elective care. This division should always be strictly considered in each individual case as the subdivision of each procedure refused or postponed by the provider will determine whether the provider proceeded in accordance with or contrary to the emergency measure. The forms of health care are then outpatient care, day care, inpatient care and health care provided in the patient's own social environment according to Section 6 of the Act [17].

In general, the analysis of legislation concerning the responsibility / liability of the state or health care providers for non-pecuniary damage must be based on Act No. 89/2012 Coll., the Civil Code, as amended, Act No. 240/2000 Coll., on Crisis Management and on Amendments to Certain Acts (Crisis Management Act), Act No. 82/1998 Coll., on Liability for Damage Caused by a Decision of a Public Authority or Maladministration, as amended,, Act No. 258/2000 Coll., on the Protection of Public Health, as amended, and Act No. 372/2011 Coll., on Health Services.

The legal regulation on compensation for non-pecuniary damage set forth in the Civil Code is only applicable to liability in relationships arising from private law, thus a healthcare provider's liability towards an injured individual. The state's liability / responsibility is not regulated by the Civil Code. Nevertheless, some of the general provisions of this law can also apply to liability in the relationships discussed below. Namely, Section 2951(2) (definition of adequate compensation), Section 2956 (compensation for injury on natural rights, including in respect of health, life and mental 
suffering), Section 2958 (scope of compensation for injury to health), and Section 2959 (scope of compensation in case of death or particularly serious bodily injury in relation to the victim's close persons) [18].

The Public Health Protection Act or the Health Services Act do not regulate liability in relationships. Nevertheless, Section 48 of the Health Services Act which regulates the conditions under which a provider may refuse to admit a patient for care, and Section 50 of the same Act, which regulates the right of a health professional not to provide a health service should be taken into account. Any violation of these rules constitutes an illegality which is one of the prerequisites for the provider's liability for non-pecuniary damage.

According to Section 48, among other things, "The health service provider chosen by the patient may refuse to admit a patient if the admission of the patient should exceed the tolerable workload or if the admission of the patient is prevented by operational reasons, staffing or technical and material equipment of the health care facility; exceeding the tolerable workload means a situation where the provision of health services to this patient should result in reducing the level of quality and safety of health services provided to patients already admitted. The provider cannot refuse to admit or terminate the care of a patient if the patient requires emergency care, in case of childbirth or where health services are essential for the protection of public or occupational health, in an emergency/crisis situation, or in case of court-ordered protective treatment unless otherwise provided by other legislation."

As provided in Section 50, among other things, "A health care professional has the right not to provide health care services if the provision of such services should directly endanger their life or seriously endanger their health. A health professional may refuse to provide health services to a patient if the provision of such services was contrary to their conscience or religious beliefs. A health professional cannot refuse to provide health services to a patient if such refusal should endanger the patient's life or seriously endanger the patient's health and the provider is unable to arrange for the provision of health services by another health professional."

In this context, note that according to Act No. 48/1997 Coll., on Public Health Insurance, as amended, the insured person has the right inter alia to "timely and local availability of fully covered services provided by the contracted health care providers of the relevant health insurance company and to the provision of fully covered services to the extent and under the conditions set out in this Act". [19] This local and timely availability is guaranteed to the patient (the insured person) by their health insurance company.

The key legislation governing liability of the state and health care providers consists of the Crisis Management Act and the Act on Liability for Damage Caused by a Decision of a Public Authority or Maladministration.

Liability for damage caused by crisis measures is stipulated in Section 36 of the Crisis Management Act as follows: "The state shall compensate loss or damage incurred by legal and natural persons in connection with crisis measures and exercises (Section 39 (4)) implemented under this Act. The state may only be exempted from this liability if it has been proved that the injured party caused the damage themselves. Monetary compensation shall be provided by the crisis management authority that imposed the crisis measure or exercise during which or as a result of which the damage or injury occurred. Compensation shall be claimed in writing by a legal or natural person, stating the reasons for the claim, from the competent crisis management authority within 6 months of becoming aware of the damage, but not later than 5 years after the damage occurred, otherwise the right shall lapse. The crisis management authority may, in circumstances eligible for special consideration, award compensation for damages after the expiry of the period for submitting an application or even without submitting an application, but not later than 5 years after the damage occurred. Compensation will not be granted to legal and natural persons who caused the damage event. The crisis management authority may claim reimbursement of the costs it has incurred in the compensation for damage from the person(s) who caused the accident, or any other event which led to emergency / crisis situation and necessitated the imposition of crisis measures." [12]

For further interpretation, the author deems it important to recall the original content of the government proposal of the provisions in Section 36 (Section 53 and Section 54 of the government proposal. [Chamber of Deputies of the Parliament of the Czech Republic, Chamber of Deputies Document No. 447, 3rd term, 19992]. The latter determined the prerequisites of the state's liability for crisis measures as follows: "Monetary compensation will be provided to legal and natural persons who have suffered damage in the course of a) activities of the authorities implementing crisis measures or rescue and liquidation work, $b$ ) the ordered provision of material resources, $c$ ) the activities referred to in Section 48(3)(f). Monetary compensation will also be granted to natural persons who have suffered damage or injury to health or property when they performed an imposed work duty, work assistance, personal assistance or voluntary assistance within an organised activity. In the event of death, compensation will be paid to the heirs."

The second relevant Act No, 82/1998 Coll., as amended, above mentioned formulates the right to compensation for damages in Sections $7 \& 8$ as follows: "The right to compensation for damages caused by an unlawful decision shall be vested in the parties to the proceedings where the decision by which the damage was caused was taken. The right to compensation for damages caused by an unlawful decision may be asserted unless otherwise provided for hereinbelow only if the final decision was annulled or reversed by the competent authority on the ground of illegality. The court deciding on compensation shall be bound by the decision of that authority. In cases other than those which deserve special consideration, a claim for compensation for damages caused by an unlawful decision may only be awarded if the injured party has exhausted, within the periods of time laid down by law, all the procedural remedies available to the injured 
party for the protection of their rights; such remedies include an ordinary appeal, an extraordinary appeal, except an application for a retrial, or any other legal remedies for the protection of the right, the exercise of which is connected with the initiation of judicial, administrative or any other legal proceedings, or an application for the stay of execution." The key point is Section 13 of the same Act which provides that "the state is liable for damages caused by maladministration. A breach of the obligation to perform an act or to render a decision within the time set by law shall also be maladministration. Where no time limit is laid down by law for the performance of an act or rendering of a decision, a breach of the obligation to perform an act or render a decision within a reasonable time shall also be regarded as maladministration. The right to compensation shall be vested in the person who has suffered damage as a result of maladministration. " [20]

Since the Ministry of Health adopted emergency measures regulating the availability of health care under the Act on the Protection of Public Health, note that those are so-called general measures [13]. The Ministry of Health's measures concerning the limitations of health care were not repealed by a court decision, but only after they had been concluded as irrelevant in view of the epidemic development in June 2021.

Before proceeding to the actual results of the assessment of liability of the state and health care providers in the next part of this paper, the author gives an overview of some relevant expert opinions on this topic.

Novotná [21] concludes "that the crisis measures of the Government of the Czech Republic were adopted in accordance with the law. Similarly, the general measures adopted by the Ministry of Health under the Act on the Protection of Public Health are considered lawful unless they interfere in a manner not permitted with the fundamental rights and freedoms of individuals. The state's liability as a result of crisis measures set out in the Crisis Act is, in principle, out of the question since the crisis measures are not the cause of the harm and injury suffered by patients as a result of the limitation or postponement of health care. If health care was limited or postponed by individual decision of a health care provider, it would be possible to hold the provider liable for the injury and harm consequently suffered since it would be caused by a violation of the Health Services Act."

By contrast, Melzer [22] notes on the issue of compensation for damages and non-pecuniary harm under the Crisis Management Act: "As previously mentioned, Section 36(1) of the Crisis Management Act only refers to compensation for damages, and not compensation for non-pecuniary harm. This text could imply that only pecuniary damages are compensated (Section 2894). On the other hand, however, the third paragraph expressly defines the method and extent of compensation for non-pecuniary damage to health arising from the performance of an imposed work duty, work assistance or assistance provided within an organised activity. This provision could either be special to paragraph 1 or it could indicate that non-pecuniary damage is to be compensated after all. The first interpretation, i.e. paragraph 3 considered as lex specialis in relation to paragraph 1 means that damage to health is only compensated in said case and other bodily injuries incurred by the victim as a result of the crisis measure are no longer compensable. The problem with the second option is that, at first sight, it leaves open the question of the type of non-pecuniary damage to be compensated. We consider that, given the considerable ambiguity in the relationship of the two provisions, the second option should be preferred. Human health and life are among the most important legal goods with the most intense protection. It would be absurd for the law to protect property interests while at the same time denying protection to these more intensely protected legal goods.

A closer look will also clarify the scope of non-pecuniary damages to be protected. Section 2956 of the Civil Code must be applied. This provision must be interpreted as clearly establishing the right to compensation for non-pecuniary damages if the facts of compensation for damages are fulfilled, which also protects (at least some) natural rights protected by the provisions of Part I of the Civil Code, i.e. in particular the personality of a person. In the present case, Section 36 of the Criminal Code also protects the life and health of persons, and therefore the right to compensation for nonpecuniary damages arises out of Section 2956 of the Civil Code in the event of interference with these goods. In the case of death, Section 2959 of the Civil Code applies."

Bílek et al. [13] concludes in their analysis that "Liability of the state for damages caused by crisis measures is objective, therefore the claim arises regardless of the fault, and the prerequisite for liability is not the illegality or incorrectness of an adopted crisis measure, but vice versa its faultlessness. It is therefore not appropriate to require the annulment of a measure taken. The actual damage and lost profits will be covered (for lost profits, see the decisions of the Supreme Court of Justice, Case No. 25 Cdo 3798/2007, Case No. 25 Cdo 1649/2007 and Case No. 25 Cdo 1422/2016) and the damage does not have to arise directly in connection with the declaration of a state of emergency, but "in connection" with the subsequent crisis measures adopted pursuant to law or in their summary. Both pecuniary and nonpecuniary damages will be compensated."

Two Supreme Court judgments [23] and [24] from the pre-covid era are applicable to the state's liability under the Crisis Management Act, but they address flood situations where public authorities had to respond quickly, urgently and in a time-sensitive manner. The judgment of 11 April 2012, Case No. 28 Cdo 2519/2011 implies that "The regulation of liability for damage arising out of or in connection with a crisis measure (including a measure taken in relation with a flood or to prevent its consequences) is a special regulation containing a special factual basis for the state's liability which is governed by the Crisis Management Act, not by Act No. 82/1998 Coll. or by a general regulation. It constitutes liability without regard to the fault (so-called strict liability) and unlike Act No. 82/1998 Coll., it does not require damage 
to be caused by an unlawful decision or maladministration. This special liability is based on the simultaneous fulfilment of three prerequisites, namely 1) the implementation of a crisis measure, 2) the occurrence of damage, and 3) a causal link between the crisis measure and the occurrence of damage. The state may be exempted from liability if it proves (the burden of proof lies on the state) that the victim caused the damage themselves. The text of Section 36(1) of the Crisis Management Act makes it clear that the state is the responsible and liable party (cf. the judgment of the Supreme Court of the Czech Republic of 17 June 2009, Case No. 25 Cdo 1649/2007 (Rc 10/2010))."

The judgment of 22 October 2009, Case No. 28 Cdo 3798/2007, removes the state's responsibility in the event of an unavoidable event, stating that "Compensation will not be granted in a situation where the state (crisis management authorities) acted upon or proceeded according to the current information."

Although the opinion below does not address compensation for non-pecuniary damage, it should be stressed as relevant. It refers to a set of communications of the Ministry of the Interior of the Czech Republic from January and February of this year, rejecting the compensation claims of injured entrepreneurs for damages (lost profits) based on the provisions of Section 36 of the Crisis Management Act. The Ministry of the Interior justifies its position as follows: "The above provision of the Crisis Management Act does not apply to crisis measures adopted in relation with the Covid-19 disease pandemic. In the Ministry's point of view, the provision of Section 36 of the Crisis Management Act applies to compensation for damages incurred by individuals solely as a result of the implementation of crisis measures that are specific in nature and directed against a specific person or a specific group of persons. On the contrary, this provision cannot be applied in the case of crisis measures that are sui generis law" [25]. Furthermore, there is an argument in the same document about the institution of special sacrifice where an individual is only granted compensation for forced individual sacrifice for the benefit of the whole, and about the exclusion of the state's liability under Act No. 82/1998 Coll. for damages caused by unlawful legislation. The Ministry denies the objective liability of the state and argues that consequences of such a serious situation as a pandemic are unforeseeable. The Crisis Management Act only regulates compensation for material damage and loss arising out of specific regulations against a specific individual. It cites the pandemic itself, not the actions of the State, as the cause of damage [25].

As regards the liability of health care providers in relation to deferring care during a state of emergency, Dostál [26] states that "the Ministry's order only applies to so-called 'elective care' under Section 5(1)(d). 'Elective care' by this definition is a residual category - it is care that is neither 'urgent' (Section 5(1)(a)), nor 'emergency' (Section 5(1)(b)), nor 'essential' (Section 5(1)(c)). If a patient requires care that fits into any of the se three categories, they are not receiving elective care and the Ministry's order does not apply.". He also notes that "In addition to inpatient care, hospitals provide as a rule extensive outpatient care in hospital offices where patients come for check-ups, tests, or minor procedures. This care is not covered by the Ministry's order, so the hospital cannot reduce this care for reasons other than those usually permitted by law."

Šolc [27] opposes these interpretations and argues that "The term 'emergency inpatient care' in the Order does not refer to the form of care to be limited - indeed, this even would not make sense in terms of the purpose of the Order which does not apply to emergency care as explained above - but to the type of health care providers to whom the Order applies. It therefore defines not the substantive but the personnel scope of the order. Nor can it rationally follow from the quoted text that the Order should be limited to inpatient care for this type of health care providers. In real world, hospitals as providers of emergency inpatient care obviously offer a wide range of outpatient services. If indeed the Order did not apply to outpatient services, hospitals could only reduce access to health care to a very small extent. However, considering the actual operation of hospitals, this would be contrary to the very purpose of the Order, or it would not be possible to achieve it. The Order should therefore be rather interpreted as allowing emergency inpatient care providers to focus their resources as much as possible on the ongoing epidemic even if this should reduce access to non-inpatient care in their health facilities. Last but not least, remember that the outpatient care in hospitals can and is likely to spread infection. If a particular health care provider concentrates patients with COVID-19 in its inpatient ward, there is an increased risk of infection in their facility despite all hygiene and organizational measures. These are also reasons for limiting medical procedures in elective care. However, it is still the case that any limitations of outpatient or one day care must always be reviewed in terms of their proportionality and necessity for the purpose of the Order."

As regards the state liability under Act No. 82/198 Coll. in view of the measures adopted by the Ministry of Health, Vojtek's conclusions [28] are particularly relevant "In this situation where the definition of the person injured by an unlawful decision cannot be based on the status of a party to the proceedings, anyone who has suffered damage as a result of the decision is actively legitimate." This makes anyone who has suffered damage as a result of a repealed general measure actively legitimate to claim compensation for damages provided the other conditions set out by law are met. Korbel [29] also states that "As regards the possibility of claiming compensation for damages from a repealed general regulation, I am inclined to the conclusion that the law allows such an interpretation". Vojtek [28] defines "A general measure is by its nature a decision sui generis". 


\section{Results}

\subsection{State Responsibility for Deferred Health Care}

For research question 1 whether the state is liable under the current legislation for personal injury / damage to health caused by the postponement of health care due to emergency measures adopted by the state during a state of emergency, the author concludes that in his point of view, the state liability for personal injury / damage to health caused by the postponement of health care during a state of emergency can generally be based on two legal regulations. The first is the Crisis Management Act and the second option is to set up a claim by reference to Act No. 82/1998 Coll., as amended. These solutions could generally be used in parallel. As regards Act No. 82/1998 Coll., two legal instruments could be considered, namely a claim for compensation for damages caused by a decision of a public authority which has been annulled on the ground of illegality, or a claim for compensation for damages caused by maladministration, specifically in a situation where the state has failed to take an appropriate action or decision within a reasonable period of time.

As regards the Crisis Management Act, see the above analysis of the legal regulation of compensation for damages and the Ministry of the Interior's rejection of the compensation claims for material damages. Based on the information from the media, the author is aware of the first judgment of a civil court which rejected compensation claims under the Crisis Management Act on grounds similar to the Ministry of the Interior's interpretation.

The author holds that the state liability for non-pecuniary damage caused by deferred health care can be inferred from the Crisis Management Act, of course, subject to the conditions set out in the Act. The author is therefore critical of the negative conclusions as provided above, in particular for the reasons set out below.

General measures adopted by the Ministry of Health concerning the limitations of health care are not legal regulations; they are decisions sui generis as can be inferred from the constant case-law and literature cited in the previous part of the paper. If they were annulled in accordance with the procedure laid down in Act No. 82/1998 Coll., such a fact could even become the basis for a claim under that Act as if the decision was annulled in an individual case. It cannot therefore be accepted that compensation claims should be rejected on the basis that the state cannot be held responsible for the accuracy of the legislation.

Moreover, the author points out that the Crisis Management Act does not distinguish between general and individual measures for the definition of crisis measures. They can include legal regulations, decisions, and measures, or de facto actions, etc. The Crisis Management Act does not even distinguish which measure was relevant for the damage incurred, but the state's liability is explicitly based on any crisis measures under this Act. If the lawmakers had intended to limit the state's liability, they would have explicitly defined other conditions under which liability arises. This is how the government's draft Crisis Management Act was formulated as documented earlier in this paper. However, the lawmakers adopted a different wording of liability for damages, not limited in any substantive way. The author agrees with the exclusion of the state liability for adopted laws, so this argument could certainly be applied to the provisions set out in the Crisis Management Act. However, not to measures that are not legal regulations.

The author is also inclined to the conclusions of Melzer [22] and refers to his findings [13] that compensation for damages under the Crisis Management Act is based on the principle that it is compensation for damages caused by the due course of law, namely by a proper crisis measure. The prerequisite for liability is therefore not illegality, but rather a duly adopted measure of the state. The liability of the state is objective. The arguments rejecting liability as non-systemic and exceptional cannot therefore be accepted. It is not possible to circumvent an unambiguous textual interpretation by a purposive teleological interpretation.

If illegality is not a prerequisite for the state liability for damages under the Crisis Management Act, the instruments excluding illegality such as the performance of a legal obligation (the state acted properly and in accordance with the crisis legislation) or a last resort should not be applied. If it is argued that COVID-19 is a force majeure event, this institute is applicable to contractual liability. In principle, the epidemic as such is a force majeure event, so the author believes this institute is logically inapplicable. Nor can it be accepted in that respect that the pandemic as such, and not the measures adopted by the state, is the cause of the damage. The examination of a causal link between the measure taken and the harm / injury is a natural part of the court's application process, but claims cannot be rejected as a rule simply on the basis that the only adequate ground in the legal sense is the epidemic as such. Then the law would not address the right of recourse and it would essentially mean that the state is only responsible for situations that it caused itself.

At the same time, the author points out that the term "damages" used in the Crisis Management Act could lead to the conclusion that only material damage is subject to compensation, but this has already been refuted by Bílek et al. [13] and Melzer [22]. The Crisis Management Act originated at a time when the Civil Code did not differentiate between the terms of material and immaterial damages. Section 36 of the Crisis Management Act has remained unchanged since it was passed. It is therefore not reasonable to believe that the lawmakers had only material damages in mind. Values such as health and life deserve increased protection in accordance with the constitutional order and cannot be disregarded for rights relating to property values - indeed, quite the opposite. 
The author is also aware of the argument of the so-called special victim institution where the state responsibility / liability is denied with reference to the fact that members of society, in general, benefit from the measures, and that compensation should therefore be provided only in the case of an individual's special extraordinary sacrifice for this general benefit. In the author's viewpoint, however, the measures would have to be applicable outside the crisis situation. The author agrees with the conclusions of Melzer [22]: "It should be highlighted, however, that the Crisis Management Act does not regulate a general claim for sacrifice in the public interest (which is rather reflected in Section 35 of the Crisis Management Act), but its specific form. Hence, for example, the fulfilment of all the subconditions that were historically present (e.g. compensation does not apply to interventions in the form of a legal regulation), or are still associated with this general claim in related legal systems cannot be required." The author notes, and above all denies the conclusion that state measures are defensible to the extent that they can harm or are likely to cause harm to life and limb in any way. These natural human rights guaranteed by the constitution cannot be sacrificed to protect from other risks to the life or health of citizens. As above mentioned, the media report about threats to human health and life from diseases posing a greater risk than covid-19 in the Czech Republic. It is necessary to examine each individual case for a causal link between the measure and the injury suffered, not in general reject claims by applying a general rule of law teleologically reducing the unambiguous language of Section 36 of the Crisis Management Act. Finally, even the consequences to health and life caused by compulsory vaccination against covid-19 are compensated under the current legislation. Similarly, there is no reason why damage caused by other state regulations affecting the health and life of individuals should not be compensated, moreover if they are imposed not within the framework of setting general standards, but according to a sui generis decision of the Ministry of Health. The protection of public health as a public interest is not limited to one selected disease.

The Ministry of Health adopted its measures under the Public Health Protection Act, but it is still a crisis measure under the Crisis Management Act. In accordance with Section 97 of this Act, the costs associated with applying the measures imposed under this Act (limited access to health care, allocation of resources, etc.) are borne by the state.

For the entire duration of the pandemic (of course, if the actual present state of affairs in the Czech Republic can be referred to as such according to general standards), the state could have adopted the essential measures as legally binding. If general measures were used, it would be justified to impute liability under the Crisis Management Act.

Regarding the prerequisites for the state liability under the Crisis Act, the author refers to [13] and [22]. The key is also the judgment of the Supreme Court, Case No. 25 Cdo 1649/2007 of 17 June 2009 that summarizes these prerequisites and establishes the objective liability of the state for the measures taken. It must be emphasized that in each individual case it will be necessary to examine the causal link of the occurrence of the injury, objective predictability, and take into account the course and effects of the epidemic itself, and the behaviour of the individual in the particular case, i.e. how his or her behaviour contributed to the occurrence of the injury / harm [30].

The obligated person is the state and claims are brought against the state authority that imposed the measure. The state is represented by the Ministry of the Interior in civil proceedings.

As mentioned above, the second possible option for claiming compensation for damages is provided in Act No. 82/1998 Coll. Since the measures adopted by the Ministry of Health concerning health care limitations and the allocation of life-saving resources have not been repealed, compensation for damages cannot be successfully claimed under this Act since the annulment of an unlawful decision is one of the necessary preconditions for entitlement for compensation. However, the author refers to the institution of maladministration which, in theory, could be considered. This would be a technical basis for a claim that the Ministry of Health failed to take all appropriate actions to protect health and life. However, the author considers this legal procedure to be quite challenging that it cannot be reasonably recommended. The Ministry of Health adopted a whole series of measures during the epidemic, and it would therefore have to be professionally examined whether or not the flow of measures was sufficient, and correct, or timely, etc.

As a purely hypothetical construct, the reason for the annulment of the Ministry of Health measures may have been the lack of power to limit / reduce care other than one day and inpatient care. In fact, the health care providers also reduced access to outpatient care with reference to the Ministry's measure. The Ministry based its decisions on Act No. 258/2000 Coll., and in particular on the possibility to impose a 'ban on some other activities'. Whether the extent of the limited care would therefore stand up to judicial review is a matter of debate. However, if the health care providers interpreted the imposed measures as they should also postpone outpatient care, their liability should also be considered.

\subsection{Liability of Health Care Providers}

For the second research question, i.e. whether the liability of health care providers for damage to health resulting from the postponement of health care due to the emergency measures adopted by the state during a state of emergency is established under the current legislation, the author concludes that the liability of health care providers must be based on Act No. 372/2011 Coll., on Health Services, in conjunction with the Civil Code. Since the health care providers followed the measures of the Ministry of Health in limiting access to and deferring care, their liability cannot be determined. If a particular provider acted contrary to the Ministry's measure and limited access to health care contra legem artis beyond the defined scope, then it would be liable under the law. In principle, what the author cited earlier in this paper applies here. 
The subject matter of a dispute may be the definition of the scope of deferred care due to the measures adopted by the government, i.e. whether the inpatient care providers can be ordered to defer outpatient care, or whether that scope was correctly interpreted by the providers. If their interpretation was wrong, they are liable for damages; if their interpretation was correct (which the author is inclined to think as is [...]), then the state's liability under the Crisis Management Act comes into play.

\section{Discussion}

In the discussion, the author highlights several key issues.

Having regard to the legal nature of a general measure, the author considered that there was a consensus that, for the purposes of Act No. 82/1998 Coll., it was a decision sui generis and if it should be annulled, the specific affected person could claim compensation for damages. If there is a relevant objection, in the context of claims by victims under the Crisis Management Act, that it is general law making, this poses a fundamental interpretation challenge. There is no logical reason why a general measure should have two different schemes whether or not it is repealed. In that respect, a uniform case-law system would be useful.

Another topic for discussion is the circumstances precluding the state liability under the Crisis Management Act. Using a linguistic and logical interpretation, the text of the Crisis Management Act leads to the conclusion that the state can objectively be held liable for material as well as non-material damages incurred by individuals in connection with the implemented measures even if they were lawful and of any legal nature. It is therefore only possible to identify circumstances precluding such liability by applying other general methods of interpretation, in particular teleological ones. If it is agreed that there need not be an element of illegality, do circumstances precluding illegality such as the performance of a legal duty or a last resort and others come into play? It would be appropriate to examine the question of damage or injury causation. Can the absence of foreseeability of damages or injuries be relied on in rejecting a claim, or is it sufficient to refer in general to the consequences of force majeure, i.e. the pandemic as such (moreover, in a situation where the state did not officially determine the parameters of the epidemic or pandemic during the state of emergency the sickness was not determined and the positive rate of tests, or the number of people in hospital, etc. were used instead).

Discussions should also be held on legislative changes that would define more precisely which measures can be adopted during a state of emergency and in what legal form. Here the author means that if measures were imposed by generally binding legislation (laws, decrees, government orders), then many issues of interpretation discussed in this paper would be avoided.

\section{Conclusion}

The interpretation ambiguities as above documented in the assessment of the state responsibility / liability during a state of emergency, both on part of the professional and lay public, are not exactly the sign of legal certainty as a fundamental building block of the rule of law. In the author's opinion, Act No. 94/2021 Coll. on emergency measures during the COVID-19 disease epidemic, does not provide an adequate solution where, in fact, the same questions arise out of its application and interpretation as in the case of the Crisis Management Act.

The author believes that it would not be appropriate to apply the institution of a general measure to across the board measures imposed by, for example, the Ministry of Health. The author proposes that the Ministry of Health should be directly authorized by the Act on the Protection of Public Health and by the Crisis Management Act to adopt a decree (generally binding legal regulation) for the purposes of an emergency, or a form of government regulations may be considered in times of emergency. Where the situation requires the form of a law given the importance of a proposed amendment, this can only be recommended.

Furthermore, the Crisis Management Act and the Public Health Protection Act should clearly define what measures can be imposed. The author does not consider it appropriate for the Ministry of Health to adopt general measures based on the vague provisions of the Act on the Protection of Public Health in a crisis situation and under a declared state of emergency. This forms a dual legal regime. The Crisis Management Act does not address the substance of the measures to be imposed whileas the Pandemic Act does.

The state should make it clear under what conditions it shall be liable, or intends to be liable for harm / damages incurred during emergency / a crisis situation. The wording of the Crisis Management Act is so general that further legislative limits should be defined. The author does not advocate casuistic legislation, but the difference in the legal regulation of liability under the Crisis Management Act and the state's responsibility / liability under other legal regulations (even historical) is obvious.

The author proposes that the state should in any case be liable for injuries / damage to health and life incurred in connection with the measures imposed to limit access to health care during a state of emergency, even those resulting from generally binding legislation. 


\section{References}

1. Government of the Czech Republic. Resolution of the Government of the Czech Republic of 12 March 2020 Number 194 [online]. Available at: https://apps.odok.cz/attachment/-/down/IHOABMNHPBSV (2020)

2. Ministry of Health of the Czech Republic. The general measure of the Ministry of Health of 16 March 2020, Ref. MZDR 12066/2020-1/MIN/KAN, of 26 October 2020, Ref. MZDR 46953/2020-1/MIN/KAN, of 23 November 2020, Ref. MZDR 46953/2020-2/MIN/KANN [online]. Available at: https://koronavirus.mzcr.cz/doporuceniposkytovatelum-zdravotni-pece/ (2020)

3. Hospital České Budějovice. Nemocnice České Budějovice opět navyšuje rezervní kapacitu pro nemocné s covid-19 [online]. Available at: https://www.nemcb.cz/aktuality/nemocnice-ceske-budejovice-opet-navysuje-rezervnikapacitu-pro-nemocne-s-covid-19/ (2021)

4. Z. Firano, F. A. Fatine. The COVID-19: Macroeconomics scenarii and role of containment in Morocco. One Health. (2020)

5. R. Aldaco, D. Hoehn, J. Laso, M. Margallo, J. Ruiz-Salmón, J. Cristobal, R. Kahhat, P. Villanueva-Rey, A. Bala, L. Batlle-Bayer, P. Fullana-i-Palmer, A. Irabien, I. Vasquez-Rowe. Food waste management during the COVID-19 outbreak: a holistic climate, economic and nutritional approach. Science of the Total Environment. (2020)

6. G. Comazzetto. The state of exception in the Italian legal system. Reflections on the impact of COVID-19 containment measures. Biolaw Journal-Rivista Di Biodiritto. 1, 35-42 (2020)

7. P. C. Barquero. The judicial authorization or rectification of urgent sanitary measures in the COVID-19 pandemic. Revista Juridica De Castilla Y Leon. (2021)

8. B. R. Kern, M. Peters. Triage - Sifting, Sorting and Deciding in the COVID-19 Pandemic: Medical Legal Aspects. Notarzt. (2020)

9. F. Gambino, C. Petrini, L. Riva. Criteria for allocation of life-saving resources during the SARS-COV-2 pandemic: ethical implications and aspects of legal liability. Annali Dell Istituto Superiore Di Sanita. 57(2), 113-120 (2021)

10. Economia. Resolution of the Presidency of the Czech National Council of 16 December 1992 on the proclamation of the Charter of Fundamental Rights and Freedoms as part of the constitutional order of the Czech Republic. Constitutional Act No. 2/1993 Coll. as amended by Constitutional Act No. 162/1998 Coll [online]. Available at: http://zakony.centrum.cz/listina-zakladnich-prav-a-svobod/

11. The Czech Republic. Constitutional Act No. 110 of 29 May 1998, Constitutional Act on the Security of the Czech Republic. In: Collection of Laws of the Czech Republic. Part 39, 5386-5387. ISSN 1211-1244 (1998)

12. The Czech Republic. Act No. 240 of 9 August 2000 on Crisis Management and on Amendments to Some Acts (Crisis Management Act). In: Collection of Laws of the Czech Republic. Part 73, 3475-3487. ISSN 1211-1244 (2000)

13. S. Bílek, Z. Caha, V. Velková. The state's responsibility towards entrepreneurs in the Czech Republic for the measures adopted in relation to the epidemic of coronavirus. Innovative Economic Symposium 2020 - Stable Development in Unstable World (IES2020). ISBN: 978-2-7598-9113-9 (2021)

14. The Czech Republic. Resolution of the Constitutional Court of the Czech Republic Ref. Pl. ÚS 12/21 of 15 March 2021 [online].

Available

at: https://www.usoud.cz/fileadmin/user_upload/Tiskova_mluvci/Publikovane_nalezy/2021/Usneseni/Pl._US_12_21_ vcetne_disentu.pdf (2021)

15. The Czech Republic. Judgment of the Municipal Court in Prague Case No. 17 A 126/2020- 84 of 23 February 2021 [online]. Available at: http://data.s3.atlascloud.cz/COVID/17A_126_2020_12.pdf (2021)

16. The Czech Republic. Act No. 258 of 14 July 2000 on the Protection of Public Health and on Amendments to Some Related Regulations In: Collection of Laws of the Czech Republic. Part 74, 3622-3662. ISSN 1211-1244 (2000)

17. The Czech Republic. Act No. 372/2011 of 6 November 2011, on Health Services and Conditions of Their Provision (Health Services Act). In: Collection of Laws of the Czech Republic. Part 131, 4730-4801. ISSN 1211-1244 (2011)

18. The Czech Republic. Act No. 89 of 3 February 2012, Civil Code. In: Collection of Laws of the Czech Republic. Part 33. 1026-1365. ISSN 1211-1244 (2012) 
19. The Czech Republic. Act No. 48/1997 of 7 March 1997, on Public Health Insurance and on Amendments to Some Related Acts. In: Collection of Laws of the Czech Republic. Part 16. 1185-1264. ISSN 1211-1244 (1997)

20. The Czech Republic. Act No. 82 of 15 April 1998 on Liability for Damage Caused by a Decision of a Public Authority or Maladministration and on Amendment to Act No. 358/1992 Coll. of the Czech National Council, on Notaries and their Activities (Notarial Code). In: Collection of Laws of the Czech Republic. Part 31, 5058-5063. ISSN 1211-1244 (1998)

21. D. Novotná. Legal aspects of damage to health as a result of epidemiological measures limiting patients' access to health care. Bulletin of Advocacy. ISSN 1210-6348 (2021)

22. F. Melzer. Compensation for damage and injuries caused by emergency measures during a coronavirus pandemic. Bulletin of Advocacy. ISSN 1210-6348 (2020)

23. The Czech Republic. Judgment of the Supreme Court of the Czech Republic Case No. 28 Cdo 2519/2011 of 11 April 2012 [online]. Available at: https://www.zakonyprolidi.cz/judikat/nscr/28-cdo-2519-2011 (2012)

24. The Czech Republic. Judgment of the Supreme Court of the Czech Republic Case No. 28 Cdo 3798/2007 of 22 October 2009 [online]. Available at: https://iudictum.cz/200420/25-cdo-3798-2007 (2009)

25. Ministerstvo vnitra České republiky. Poskytnutí informace - náhrady škody způsobené opatřeními států v souvislosti s pandemii nemoci COVID-19 [online]. Available at: https://www.mvcr.cz/clanek/poskytnuti-informace-nahradyskody-zpusobene-opatrenimi-statu-v-souvislosti-s-pandemii-nemoci-covid-19.aspx (2021)

26. O. Dostál. Práva pacientů v nouzovém stavu: Nemám COVID, potřebuji péči [online]. Available at: https://advokatnidenik.cz/2020/03/19/prava-pacientu-v-nouzovem-stavu-nemam-covid-potrebuji-peci/ (2020)

27. M. Šolc, P. Šustek. Nouzový stav: omezuje Ministerstvo zdravotnictví práva pacientů? [online]. Available at: https://www.pravniprostor.cz/clanky/ostatni-pravo/nouzovy-stav-omezuje-ministerstvo-zdravotnictvi-pravapacientu (2020)

28. P. Vojtek, Liability for Damage in the Exercise of Public Authority. Praha: C. H. Beck $3^{\text {rd }}$ ed. ISBN: 978-80-7400427-8 (2012)

29. F. Korbel, in: F. Ištvánek, P. Simon, F. Korbel. Act on Liability for Damage Caused by a Decision of a Public Authority or Maladministration. Praha: Wolters Kluwer. ISBN 9788075525215. (2017)

30. The Czech Republic. Judgment of the Supreme Court, Case No. 25 Cdo 1649/2007 of 17 June 2009 [online]. Available at: https://www.zakonyprolidi.cz/judikat/nscr/25-cdo-1649-2007 (2009) 